\title{
Prevalence of Skin Diseases in a Slum Area
}

\author{
Neelam Kotwal*1, Sunil Kumar ${ }^{2}$, Monika Malhotra ${ }^{2}$ and Mohammad Sarwar Mir ${ }^{3}$ \\ ${ }^{1}$ Former Medical Officer at Shri Mata Vishnu Devi Shrine Board, India \\ ${ }^{2}$ MO Grade 1 ESIC Hospital, India \\ ${ }^{3}$ Senior Resident, SKIMS, India
}

Submission: January 17, 2019; Published: April 09, 2019

*Corresponding author: Neelam Kotwal, Former Medical Officer at Shri Mata Vishnu Devi Shrine Board, Jammu, India

\begin{abstract}
Background: Skin diseases are one of the most common health problems.

Objectives: The objectives of this study are to determine the prevalence of skin diseases in a Urban slum.

Methods: A community survey was conducted in a urban locality with 4000 inhabitants, to obtain socio-demographic data and identify individuals with skin diseases.

Results: Of 4000 individuals attending the health camps,800 had one or more Skin diseases. The overall prevalence of SDs was $20.00 \%$.The most common SD categories were eczemas, fungal infection, pigment disorders and acne. The prevalence of the diseases was higher in females. The children were the most common group affected.

Conclusion: Skin disease is very common in community. Targeted training should enable health-care workers to prevent, accurately diagnose and manage these problems on site.
\end{abstract}

Keywords: Prevalence; Community; Skin disease; slums

\section{Introduction}

Skin diseases are one of the most ubiquitous health problems, affecting 1 in 5 persons in the UK and 1 in 3 in the US, but there are large differences between countries, climates and cultures [1]. The highest prevalence has been reported from developing countries and poor areas. In the mountainous region of northern India, the overall prevalence is $45.3 \% 5$, while, in rural Sumatra, it is $28.2 \%$. In Africa, reported prevalence (Figure 1) vary between $11.7 \%$ in Bamako, Mali, to $48 \%$ in rural Ethiopia. The published prevalence figures in children are also high, 32\% in Kenya, 34\% in Mali, 31.3\% in Hong Kong and 38.8\% in northern India.

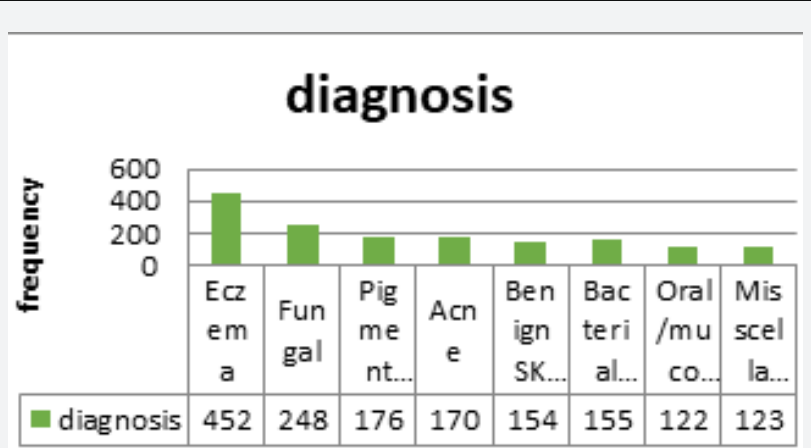

Figure 1: Skin diseases and prevalence (Total population is 4000).
Figures of this kind reported from various countries are difficult to compare due to differences in study design, the seasonality of certain diseases and uncertainty in terms of census statistics [2]. A major reason for targeting skin diseases in the developing world is that the majority are transmissible and therefore potentially preventable and controllable. Most of the available statistics on the pattern of skin diseases have been based on hospital or private practice and can provide a very crude indication of true prevalence and incidence in a community, as many social and economic factors affect the decision to seek medical advice. So, the present study was designed to determine the actual extent of the skin disease problem in urban areas [3].

\section{Methods}

It was a community survey of a slum. All community members consulting for skin problems at the health camp were examined. The majority of diagnoses were based on the patient's history and clinical signs. Those with recurrent or long lasting SDs were interviewed about symptoms, feelings, daily activities, wearing clothes, social/leisure activities, sport, work/school, personal relationships, sexual activity and treatment. The demographic and clinical data were documented on patient record forms prepared for the study. All patients were provided with free consultations and medicines. 


\section{Data Analysis}

The data were entered in the SPSS 20.0 program and analysed.

\section{Results}

Out of total 4000 community members. a total of 800 patients had one or other form of disease yielding an overall prevalence rate of $20.00 \%$.

\section{Discussion}

The overall prevalence of skin diseases in this study was $20.00 \%$. As in many other studies from developing countries, children and females were more vulnerable than males. One fifth of the inhabitants affected are a fairly high prevalence for SDs, but it is considerably lower than what has been reported from other developing countries in Asia and Africa [4-8].

Eczemas, including photodermatitis, were the most common SDs in our study. The similar findings were obtained by Griils, et al. [4] \& Saw SM, et al. [5]. The number of infections and infestations were surprisingly low in the studied community. In northern India, infections and infestations accounted for 33\%3, in Sumatra 49.5\%4 and in Ethiopia 79\%8. This difference might be due to the fact that our study was conducted urging a relatively cool season and it is well known that there are large seasonal variations in the incidence of skin diseases, especially infectious skin diseases, which are more common in tropical and subtropical climate zones.

\section{Conclusion}

Skin diseases are common in the urban communities. With the limited resources available and the lack of dermatologists, we are convinced that information and training for health-care workers will be a cost-effective way to prevent, diagnose, treat or refer these most common skin problems on site.

\section{References}

1. Mubashar Mashqoor Mir, Mohammad Sarwar Mir (2018) Prevalence of Skin Diseases: A Community Based Survey. Sch J App Med Sci 6(3): 1302-1304.

2. Shrestha DP, Gurung D, Rosdahl I (2012) Prevalence of skin diseases and impact on quality of life in hilly region of Nepal. Institute of Medicine Journal 34(3): 44-49.

3. Abdel Hafez K, Abdel Aty MA, Hofny ER (2003) Prevalence of skin diseases in rural areas of Assiut Governorate, Upper Egypt. Int J Dermatol 42(11): 887-892.

4. Grills N, Grills C, Spelman T, Stoove M, Hellard M, et al. (2012) Prevalence survey of dermatological conditions in mountainous north India. Int J Dermatol 51(5): 579-587.

5. Saw SM, Koh D, Adjani MR, Wong ML, Hong CY, et al. (1999) A population-based prevalence survey of skin diseases in adolescents and adults in rural Sumatra, Indonesia, 1999. Trans R Soc Trop Med Hyg 95(4): 384-388.

6. Gibbs S (1996) Skin disease and socioeconomic conditions in rural Africa: Tanzania. Int J Dermatol 35(9): 633-639.

7. Satimia FT, McBride SR, Leppard B (1998) Prevalence of skin disease in rural Tanzania and factors influencing the choice of health care, modern or traditional. Archives of dermatology 134(11): 1363-1366.

8. Figueroa JI, Fuller LC, Abraha A, Hay RJ (1998) Dermatology in southwestern Ethiopia: rationale for a community approach. Int J Dermatol 37(10): 752-758.

\section{Your next submission with Juniper Publishers} will reach you the below assets

- Quality Editorial service

- Swift Peer Review

- Reprints availability

- E-prints Service

- Manuscript Podcast for convenient understanding

- Global attainment for your research

- Manuscript accessibility in different formats

( Pdf, E-pub, Full Text, Audio)

- Unceasing customer service

Track the below URL for one-step submission https://juniperpublishers.com/online-submission.php 